\title{
Some Growth Promoting Essential Mineral Elements Alleviates The Salinity Effect on Nitrate Reductase and Hill Reaction Activities in Cotton (Gossypium hirsutum) cv. "CIM 496"
}

\author{
Rizwana Jabeen $^{1,2}$, Rafiq Ahmad ${ }^{1}$ \\ ${ }^{1}$ Department of Botany Government College for Women Shahrah-e-Liaquat, Karachi, Pakistan \\ ${ }^{2}$ Department of Botany, University of Karachi, Karachi, Pakistan
}

Email address:

rizcapricon_786@yahoo.com(R. Jabeen), agrisalt@gmail.com (R. Ahmad)

\section{To cite this article:}

Rizwana Jabeen, Rafiq Ahmad. Some Growth Promoting Essential Mineral Elements Alleviates The Salinity Effect on Nitrate Reductase and Hill Reaction Activities in Cotton (Gossypium hirsutum) cv. "CIM 496". Journal of Plant Sciences. Vol. 3, No. 2, 2015, pp. 54-58.

doi: $10.11648 /$ j.jps.20150302.12

\begin{abstract}
The effect of salinity was observed on the activity of nitrate reductase and hill reaction activity in the leaves of Cotton (Gossypium hirsutum L.) cv. "CIM 496" grown in large size plastic pot culture, irrigated with sea salt concentrations of $0.0 \%$ (EC iw: $0.6 \mathrm{dS} / \mathrm{m}), 0.4 \%(\mathrm{EC}$ iw: $6.2 \mathrm{dS} / \mathrm{m})$ and $0.8 \%$ (EC iw: $10.8 \mathrm{dS} / \mathrm{m})$ and subjected to foliar application with nonspray (control), water spray, $\mathrm{KNO}_{3}(500 \mathrm{ppm}), \mathrm{KCl}(500 \mathrm{ppm})$, Urea(1000 ppm), Fe-EDTA (5ppm), $\mathrm{MnCl}_{2}(5 \mathrm{ppm})$ and $\mathrm{MoO}_{3}$ $(5 \mathrm{ppm})$ alone and their mixture. Foliar spray of the mixture showed better result as compared to that of above mentioned individual mineral. Conclusion made on the comparative performance of nitrate reductase and hill reaction enzymes under above number of treatments in the leaves of cotton growing under various sea salt concentrations is given below: Nitrate Reductase Activity (NRA): Nonspray $<$ water spray $<\mathrm{KCl}<\mathrm{Mo}<\mathrm{KNO}_{3}<\mathrm{Urea}<\mathrm{KNO}_{3}+\mathrm{Mo}<\mathrm{KNO}_{3}+\mathrm{Fe}+\mathrm{Mn}+\mathrm{Mo}$; $\mathrm{Hill}$ Reaction Activity (HRA): Nonspray $<$ water spray $<\mathrm{KNO} 3<\mathrm{Fe}<\mathrm{Mn}<\mathrm{KNO}_{3}+\mathrm{Fe}<\mathrm{KNO}_{3}+\mathrm{Mn}<\mathrm{KNO}_{3}+\mathrm{Fe}+\mathrm{Mn}+\mathrm{Mo}$.
\end{abstract}

Keywords: Salinity, Gossypium, EC iw (Electrical Conductivity of Irrigation Water), Foliar Spray, Nitrate Reductase Activity, Hill Reaction Activity

\section{Introduction}

Excessive soil salinity can result from natural processes, or from crop irrigation with saline water under poor drainage conditions. This effect is mostly reported in semi-arid to arid regions where it inhibits the growth and yields of crop plants $[1,2,3]$. The physiology of plant responses to salinity and their relation to salinity resistance have been much researched and frequently reviewed in recent years e.g. [4, 5, $6,7,8,9]$.The ability of plants to tolerate salt is determined by multiple biochemical pathways that facilitate retention and/or acquisition of water, protect chloroplast functions, and maintain ion homeostasis. Essential pathways in this connection are referred those which lead to synthesis of osmotically active metabolites, specific proteins, and certain free radical scavenging enzymes [10]. Therefore, foliar application of essential mineral elements is an alternative approach to cope with saline rooting medium. In this respect
$[11,12,13]$ stated that foliar fertilization of both macro and micronutrient is practiced whenever, nutrients uptake through the root system is restricted due to salt stress. Foliar spray did not only increase the crop yields but also reduce the quantities of fertilizer applied through soil. Islam et al., [14] used $0.1 \% \mathrm{KNO}_{3}$ as foliar spray on jute plant leaves and obtained good results whereas, $250 \mathrm{ppm}$ of $\mathrm{KNO}_{3}$ produce promising results in Lagenaria siceraria documented by [15]. Jabeen \& Ahmad [16] studied the response of cotton grown at high salinity supplemented with foliar application of $\mathrm{KCl}$ (500 ppm) and $\mathrm{NH}_{4} \mathrm{NO}_{3}(500 \mathrm{ppm})$ alone and in mixture offset the inhibitory effect due to salinity. Nitrate reductase (NR) contains molybdenum, it is apparent that in higher plants it plays important role in facilitating the assimilation of nitrate. In Prosopis alba [17] found only highest $\mathrm{NaCl}$ concentration affected the nitrate content and nitrate reductase activity in leaves and roots when treated 0, 300 and $600 \mathrm{mmol}^{-1} \mathrm{NaCl}$. Nitrate reductase activity (NRA) is 
considered as the main limiting step in nitrogen assimilation in most plants [18, 19]. The activity of nitrate reductase depends of various factors, including the level of nitrate supply, the plant species, the plant age, and has important consequences for mineral nutrition and carbon economy of plants. In general, when the external nitrate supply is low, a high proportion of nitrate is reduced in the roots. Chaves et al., [20] Reported that photosynthesis is a key factor in the determination of plant development. The decrease in crop performance detected in various plant groups exposed to salinity is linked to the decline in photosynthesis. Reduction in the photosynthetic capability of various plant species by salt stress has been documented in a number of reports [21, 22,23 ]. Foliar supply of manganese (Mn) in suitable quantity may result an increase in hill reaction activity and growth rate of cells in barley under saline rhizosphere [24]. Manganese (Mn) has been known for many years as an essential unique metallo-enzyme required for oxygenic photosynthesis in all plants and cyanobacteria in the water oxidizing process [25]. The function of $\mathrm{Mn}$ at the cellular level of plant is to bind firmly to lamellae of chloroplast, possibly to the outer surface of thylakoid membranes, affecting the chloroplast structure and photosynthesis [26].The present study was undertaken to see the effect of foliar application of some sodium antagonistic essential minerals on plants raised with sea salt water irrigation at sandy loam soil. The aim was to investigate whether it will inhibit toxic effect of excessive sodium and improve physiological parameters like nitrate reductase and Hill reaction activity.

\section{Materials and Methods}

Since broader leaf plants provide greater surface for retention of minerals given through foliar spray, commercially important Gossypium hirsutum cv. "CIM 496" cotton) included in family Malvaceae was selected for present investigation. The seeds were obtained from Agriculture University, Faisalabad, Pakistan. An experiment was conducted in large size plastic pots during autumn: April December 2006. A set of 180 large size plastic pots containing approximately $18 \mathrm{Kg}$ of sandy loam soil each having basal outlet for drainage were used in this experiment. Cow dung manure with $\mathrm{pH} 7.9$ was added in the soil at 9:1 ratio (w/w) whereas NPK (Nitrogen, Phosphorus and Potassium) fertilizer concentrations were followed by [27, 28]. The seeds were delinted with concentrated $\mathrm{H}_{2} \mathrm{SO}_{4}$ for one minute to remove the fiber and immediately washed with running distilled water and then surface sterilized with $0.1 \%$ (w/v) $\mathrm{HgCl}_{2}$ for five minute. Composition of foliar supply medium was based on potassium $\left(\mathrm{K}^{+}\right)$as macro element and some essential trace elements which being bivalent and trivalent show antagonism with monovalent sodium $\left(\mathrm{Na}^{+}\right)$ were given in concentration with potassium $\left(\mathrm{K}^{+}\right)$, which appeared to be growth promoting for plants raised under saline water irrigation. Experiment was divided into XII sets i:e INon-spray, II-Foliar spray with water, III-Foliar spray with Fe-EDTA (5 ppm), IV-Foliar spray with $\mathrm{MnCl}_{2},(5 \mathrm{ppm}), \mathrm{V}-$
Foliar spray with $\mathrm{MoO}_{3}$ (5 ppm), VI-Foliar spray with $\mathrm{KNO}_{3}$ (500 ppm), VII-Foliar spray with $\mathrm{KCl}$ (500 ppm), VIII-Foliar spray with Urea (1000 ppm) IX-Foliar spray with $\mathrm{KNO}_{3}(500$ ppm)+ Fe-EDTA (5 ppm), X-Foliar spray with $\mathrm{KNO}_{3}(500$ ppm) $+\mathrm{MnCl}_{2}$ (5 ppm), XI-Foliar spray with $\mathrm{KNO}_{3}(500$ ppm) $+\mathrm{MoO}_{3}(5 \mathrm{ppm})$ and XII-Foliar spray with $\mathrm{KNO}_{3}(500$ $\mathrm{ppm})+\mathrm{Fe}-\mathrm{EDTA}(5 \mathrm{ppm})+\mathrm{MnCl}_{2}(5 \mathrm{ppm})+\mathrm{MoO}_{3}(5 \mathrm{ppm})$. A Randomized Complete Block Design (RCBD) with five replications was used. Out of a total 180 pot 15 were used in each foliar spray set, comprising of three different irrigation treatment i: e $0.0 \%$ sea salt irrigation water (EC iw: $0.6 \mathrm{dS} / \mathrm{m}$ ), $0.4 \%$ sea salt irrigation water (EC iw: $6.2 \mathrm{dS} / \mathrm{m}$ ) and $0.8 \%$ seasalt irrigation water (EC iw: $10.8 \mathrm{dS} / \mathrm{m}$ ) given to five pots under each treatment. Liquid transparent soap solution with concentration of $100 \mathrm{ppm}$ was used as a surfactant for each treatment. Spray solution of $500 \mathrm{~mL}$ was applied to each plant with fine mist sprayer whereas water spray set was sprayed with only water. The $\mathrm{pH}$ values of spray solution was in range of $3.0-5.5$ which are optimal ranges for the maximum uptake of mineral nutrients as reported by[29].The plants were sprayed constantly till the leaves were entirely showery and the solution ran off the leaves. Control $(0.0 \%$ sea salt irrigation water) treatment plants were irrigated with $3 \mathrm{~L}$ of tap water and plants under saline treatments were irrigated with same volume of water with their respective sea salt concentrations ensuring proper leaching. Insecticides were used to control pest management during the growth season according to directions. Fresh cotton leaves sample were collected for NRA by the method [30] from $3^{\text {rd }}$ and $4^{\text {th }}$ node at grand period of growth and then central portion of leaves were cut into discs of $1.0 \mathrm{~cm}$ in diameter avoiding the main vein. The NRA spectrophotometric assay method was based on incubation of fresh leaf tissue $(300 \mathrm{mg})$ in $10.0 \mathrm{~mL}$ of a buffer mixture comprising $25 \mathrm{mMol} / \mathrm{L}$ potassium phosphate buffer (pH 7.2), $25 \mathrm{mMol} / \mathrm{L} \mathrm{KNO}_{3}$ and $1 \%(\mathrm{w} / \mathrm{v})$ n-propanol . In order to induce anaerobic conditions in the incubation medium, the system was subjected to vacuum infiltration three times to remove air from the tissue. The buffer medium was maintained in the dark at $30^{\circ} \mathrm{C}$ for 60 minutes. The nitrite produced by action of the NR enzyme was determined by drawing $0.5 \mathrm{~mL}$ aliquot of the incubation medium, and treating this sample with $0.5 \mathrm{~mL}$ of $10 \mathrm{~g} / \mathrm{L}$ sulfanilamide in 3 $\mathrm{mol} / \mathrm{L} \mathrm{HCl}$ and $0.5 \mathrm{~mL}$ of $0.2 \mathrm{~g} / \mathrm{L} \mathrm{N}$-(1-naphtyl)ethylenediamine dihydrochloride. After 20 minutes, the solution was diluted to $4.5 \mathrm{~mL}$ with deionized water, and the absorbance was noted at $540 \mathrm{~nm}$. Hill reaction activity was conducted with Ferricyanide Dye ${ }^{1,2,3}$ as an electron acceptor by using the method [31]. $300 \mathrm{mg}$ of fresh leaves samples were deveined and grind with $5 \mathrm{ml}$ of isolating medium consisting of $10 \%(\mathrm{w} / \mathrm{v})$ polyethylene glycol and $0.1 \mathrm{M}$ potassium phosphate buffer adjusted to a $\mathrm{pH}$ of 7.6. The homogenate was squeezed through about eight layers of clean cheese cloth. Chloroplast extracts were centrifuged at $8000 \mathrm{~g}$ for $3 \mathrm{~min}$. After two washes with $10 \mathrm{ml}$ of the isolating medium, the chloroplasts were stored for short periods in the isolation medium at $1{ }^{0} \mathrm{C}$. The measurement of the Hill reaction is accomplished as follows: chloroplast aliquot is mixed with $0.05 \mathrm{M}$ phosphate buffer with $\mathrm{pH} 7.0$, $0.4 \mathrm{M}$ sucrose, $0.01 \mathrm{M} \mathrm{KCl}$ mixture medium, and $0.1 \mathrm{ml}$ of 
$0.01 \mathrm{M}$ potassium ferricyanide is added. The optical density of the mixture is recorded at $625 \mathrm{~nm}$. The test tube or cuvette is illuminated, and then $0.1 \mathrm{ml}$ of $0.2 \mathrm{~N}$ sodium citrate and $0.1 \mathrm{ml}$ of $0.01 \mathrm{~N}$ ferric chloride in $0.1 \mathrm{~N}$ acetic acid are added, followed by $0.1 \mathrm{ml}$ of $0.1 \mathrm{M}$ orthophenanthroline in absolute alcohol and allowing four minutes for complete color development, the optical density is compared to that of a control cuvette which had not been illuminated, but is otherwise identical. All the data were statistically analyzed by computer program Costat 3.03 and SPSS version 11[32]. Mean separation of data was carried out using Duncan Multiple Range Test [33].

\section{Results and Discussion}

\subsection{Activity of Nitrate Reductase (NRA)}

In present study in Gossypium hirsutum it is observed that leaf nitrate reductase activity increased at $0.4 \%$ sea salt irrigation water (EC iw: $6.2 \mathrm{dS} / \mathrm{m}$ ) irrespective of any foliar treatment. The inhibitory effect was found at $0.8 \%$ sea salt irrigation water (EC iw: $10.8 \mathrm{dS} / \mathrm{m}$ ) irrespective of any foliar treatment (table 1). Foliar spray of $\mathrm{KNO}_{3}$ with three microelement ( $\mathrm{Fe}, \mathrm{Mn}, \mathrm{Mo}$ ) mixture proved to be best spray medium, while the foliar spray of $\mathrm{KNO}_{3}$ with (Mo) was second best medium, foliar spray of alone, Urea, $\mathrm{KNO}_{3}$, Mo and $\mathrm{KCl}$ was found at third, fourth, fifth and sixth order respectively. Hence the spray of mineral elements overcomes the toxic effect of root zone salinity of sea salt irrigation. Conclusion made on the comparative performance of this enzyme under above number of treatments in the leaves of cotton growing under various regimes of sea salt irrigation water is shown as follows: Nonspray $<$ water spray $<\mathrm{KCl}<$ $\mathrm{Mo}<\mathrm{KNO}_{3}<$ Urea $<\mathrm{KNO}_{3}+\mathrm{Mo}<\mathrm{KNO}_{3}+\mathrm{Fe}+\mathrm{Mn}+\mathrm{Mo}$. In tanner grass (Brachiaria radicans Napper) [34] reported that nitrate reductase activity was enhanced when fertilized with $\mathrm{NaNO} 3$ as comparison with $\mathrm{NH}_{4} \mathrm{Cl}$ and Urea while the application of molybdenum in the absence of external nitrogen improved NRA without affecting leaf and stalk growth. Whereas in the presence of nitrogen, application of the molybdenum levels limited leaf NRA and plant development. Highest levels of NRA was found by [35] in the leaf of Verbascum L. species in comparison with root and stem, significant differences were found between the samples collected from different altitudes. The NRA was found highest in Verbascum olympicim Bioss, and lowest in Verbascum lagurus Fisch and Mey. In Azospirillium brasilense was reported [36] the application of molybdenum leads to an increased accumulation of potassium ions up to 2 folds compared to the respective molybdenum untreated plants under drought condition. Activity of nitrate reductase in leaf is reported to be dependent on the source of nitrogen [37] and continuous supply of nitrates through the xylem [38, 39]. Interactions between the different nitrogen sources and molybdenum have been worked out on NRA by [40].

Table 1. Effect of foliar spray of mineral nutrients and sea salt irrigation water of different salinity levels on nitrate reductase activity (NRA) ( $\mu$ mole $\mathrm{NO}_{2} / g$ f.w.t/min) in Gossypium hirsutum.

\begin{tabular}{|c|c|c|c|}
\hline Foliar Spray Treatment / Sea salt irrigation water Treatment (\%) & $0.0 \%(E C: 0.6 \mathrm{dS} / \mathrm{m})$ & $0.4 \%(E C: 6.2 \mathrm{dS} / \mathrm{m})$ & $0.8 \%$ (EC: $10.8 \mathrm{dS} / \mathrm{m})$ \\
\hline Non-Spray & $15.93 \mathrm{a}$ & $16.39 \mathrm{a}$ & $14.26 \mathrm{~b}$ \\
\hline Foliar spray with water & $17.04 \mathrm{a}$ & $17.4 \mathrm{a}$ & $16.67 \mathrm{~b}$ \\
\hline Foliar spray with KNO3 (500 ppm) & $18.52 \mathrm{a}$ & $18.89 \mathrm{a}$ & $17.19 \mathrm{a}$ \\
\hline Foliar spray with Urea(1000 ppm) & $20.65 \mathrm{a}$ & $20.83 \mathrm{a}$ & $19.01 \mathrm{~b}$ \\
\hline Foliar spray with MoO3 (5 ppm) & $18.16 \mathrm{~b}$ & $17.87 \mathrm{a}$ & $18.00 \mathrm{~b}$ \\
\hline Foliar spray with $\mathrm{KCl}(500 \mathrm{ppm})$ & $17.59 \mathrm{a}$ & $17.71 \mathrm{a}$ & $16.83 \mathrm{~b}$ \\
\hline Foliar spray with KNO3 (500 ppm) + MoO3 (5 ppm) & $21.57 \mathrm{~b}$ & $23.31 \mathrm{a}$ & $20.93 \mathrm{a}$ \\
\hline
\end{tabular}

Mean followed by different letters in the same column differ significantly at 95\% probability level according to New Duncan's Multiple Range Test.

\subsection{Hill Reaction Activity (HRA)}

Hill reaction activity determine by the reduction of potassium ferricyanide increased at $0.4 \%$ sea salt irrigation water (EC iw: $6.2 \mathrm{dS} / \mathrm{m}$ ) but the inhibitory effect was found at $0.8 \%$ sea salt irrigation water (EC iw: $10.8 \mathrm{dS} / \mathrm{m}$ ) irrespective of any foliar treatment (Table 2) in present investigation. Foliar spray of $\mathrm{KNO}_{3}$ with three microelement (Fe, Mn, Mo) mixture occupies $1^{\text {st }}$ position in improving this reaction, while the spray of $\mathrm{KNO}_{3}$ with $(\mathrm{Mn}), \mathrm{KNO}_{3}$ with $(\mathrm{Fe})$ were found second and third best medium, foliar spray of alone, $\mathrm{Mn}, \mathrm{Fe}$ and $\mathrm{KNO}_{3}$, was found at fourth, fifth and sixth order. Conclusion made on the comparative performance of this enzyme under above number of treatments in the leaves of cotton growing under various dilutions of sea salt water irrigation is given as follows: Nonspray< water spray< $\mathrm{KNO} 3<\mathrm{Fe}<\mathrm{Mn}<\mathrm{KNO}_{3}+\mathrm{Fe}<\mathrm{KNO}_{3}+\mathrm{Mn}<\mathrm{KNO}_{3}+\mathrm{Fe}+$
$M n+M o$. Similar result of inhibitory effect of salinity on Hill reaction activity were also documented by others [41, 42, $43,44]$. In sunflower plants [45] exogenous supply of micronutrients i.e., manganese and boron alone and their mixture partially offset the inhibitory effect of salt stress and improved the Hill reaction activity irrespective to their growth under non saline or saline conditions. In Oryza sativa L. cv. Safari [46] found similar results when treated with varying $\mathrm{Mn}$ concentrations between 0.125 and $32 \mathrm{mg} / \mathrm{L}$ in nutrient solutions. The plant shoots and the thylakoid membranes showed an overall increase in Mn content and the photosynthetic electron transport rates coupled to PSII and PSI also showed a significant increase up to $8 \mathrm{mg} / \mathrm{L} \mathrm{Mn}$ treatment. Krogmann \& Jagendorf [47] reported that ferricyanide reduction is seen to be proportional to the concentration of chlorophyll added, and only $12 \%$ less than the dye reduction achieved under similar conditions. 
Ferricyanide reduction is also found to be directly proportional to the duration of exposure to saturating light. The method appears to be usable in measuring the reduction of ferricyanide by the Hill reaction, at low oxidant concentrations, over short periods of time. The substitution of quinones for ferricyanide proved impractical due to complicating nonenzymatic reactions between the quinones and ferric chloride. In cotton [48] reported, actively reduction of ferricyanide when assay for Hill reaction activity was increased $133 \%$ with $10 \%(\mathrm{w} / \mathrm{v})$ polyethylene glycol when replaced by $0.5 \mathrm{M}$ sucrose at $\mathrm{pH}$ 7.6.

Table 2. Effect of foliar spray of mineral nutrients and sea salt irrigation water of different salinity levels on Hill reaction activity (HRA) / gram fresh weight ( $\mu$ mole ferricyanide/mg chlorophyll/hr) in Gossypium hirsutum.

\begin{tabular}{|c|c|c|c|}
\hline Foliar Spray Treatment/ Sea salt irrigation water Treatment (\%) & $0.0 \%(E C: 0.6 \mathrm{dS} / \mathrm{m})$ & $0.4 \%(\mathrm{EC}: 6.2 \mathrm{dS} / \mathrm{m})$ & $0.8 \%(E C: 10.8 \mathrm{dS} / \mathrm{m})$ \\
\hline Non-Spray & $0.029^{\mathrm{a}}$ & $0.037^{\mathrm{b}}$ & $0.028^{\mathrm{a}}$ \\
\hline Foliar Spray with water & $0.048^{\mathrm{a}}$ & $0.056^{\mathrm{a}}$ & $0.041^{\mathrm{c}}$ \\
\hline Foliar spray with $\mathrm{KNO}_{3}(500 \mathrm{ppm})$ & $0.060^{\mathrm{b}}$ & $0.066^{\mathrm{a}}$ & $0.058^{\mathrm{c}}$ \\
\hline Foliar spray with Fe-EDTA (5 ppm) & $0.057^{\mathrm{a}}$ & $0.065^{\mathrm{b}}$ & $0.059^{\mathrm{a}}$ \\
\hline Foliar spray with $\mathrm{KNO}_{3}(500 \mathrm{ppm})+\mathrm{MnCl}_{2}(5 \mathrm{ppm})$ & $0.063^{\mathrm{a}}$ & $0.068^{\mathrm{b}}$ & $0.065^{\mathrm{a}}$ \\
\hline Foliar spray with $\mathrm{KNO}_{3}(500 \mathrm{ppm})+\mathrm{Fe}-\mathrm{EDTA}(5 \mathrm{ppm})$ & $0.062^{\mathrm{b}}$ & $0.067^{\mathrm{a}}$ & 0.061 \\
\hline
\end{tabular}

Mean followed by different letters in the same column differ significantly at 95\% probability level according to New Duncan’s Multiple Range Test.

\section{Conclusions}

Our results have highlighted the usefulness of foliar spray practice in plant growth regulation. One of the more significant findings to emerge from this study is that foliar application of macro and micro mineral elements can improve plant physiological efficiency, including nitrate reductase and Hill reaction activities under saline environmental conditions. In present investigation the critical values of salts in rooting medium beyond which retardation occurs at both NRA and HRA enzymatic activities was significantly extended due to foliar supply of above mentioned essential minerals alone or in mixture of two or three salts, which could provide incentive to grow salt tolerant crop through foliar application of essential sodium antagonistic mineral elements at a bit higher levels of salinities.

\section{References}

[1] Greenway, H. \& Munns, R. 1980. Mechanism of salt tolerance in non-halophytes, Annu. Rev, Plant Physiol., 31: 149-190.

[2] Tanji, K.K. 1990. Nature and extent of agricultural salinity. In: Agricultural Salinity Assessment and Management (Tanji, K K eds.), pp. 1-13. ASCE, New York.

[3] Kapoor, K. \& Srivastava, A. 2010. Assessment of salinity tolerance of Vigna mungo Var.Pu-19 using ex vitro and in vitro methods. Asian Journal of Biotechnology 2(2): 73-85.

[4] Pasternak, D. \& Pietro, S. 1985. Biosalinity in action: Bioproduction with saline water. Plant Soil., 89:1-413.

[5] Cheeseman, J.M. 1988. Mechanism of salinity tolerance in plants. Plant Physiol., 87: 547-550.

[6] Lauchli, A. 1990. Calcium, salinity and the plasma membrane. In: Calcium on plant growth and development. In Current Topics in Plant Physiology Series, Vol.4.( Leonard, R.T. and Hepler, P.K eds.), pp. 26-35. ASPP, Rockville, M.D.
[7] Rengel, Z. 1992. The role of calcium in salt toxicity. Plant Cell Environ. 15: 625-632.

[8] Munns, R. 1993. Physiological processes limiting plant growth in saline soils: Some dogmas and hypothesis. Plant Cell Environment., 16: 15-24

[9] Neumann, P.M. 1997. Salinity resistance and plant growth revisited. Plant cells and Environ., 20:1193-1198.

[10] Paridaa, A.K. \& Dasa, A.B. 2005. Salt tolerance and salinity effects on plants: A Review.Ecotoxic. and Environm., 60(3): 324-349.

[11] El - Saidi, M. T. 1997. Salinity and its effects on growth, yield and some physiological processes of crop plants. In: Strategies for improving salt tolerance in higher plants. (Jaiwal, P.K., Singh, R.P. and Gulati, A., eds.), pp. 111-127. Oxford and IBH Publishing Co. Pvt. Ltd., New Delhi.

[12] El-Fouly, M.M., Moubarak, Z.M. \& Salama, Z.A. 2002. Micronutrient foliar application increase salt tolerance of tomato seedlings. Acta Hort., 573: 467-472.

[13] El-Fouly, M. M., Moustafa, H. A. \& Attia, K. A. 2006. Chemical composition of soyabeans from plants treated with growth retardants. Pest Sci., 1(5):189-190.

[14] Islam, A., Sayeed, A., Absar, N., Ibrahim, M., Mondal, H. \& Alam, S. 2003. Effect of NPK fertilizers and cowdung in combination with foliar spray of chemicals on growth and quality of jute plant. Jour. Biol. Sci., 3(11):1016-1025.

[15] Ahmad, R. \& Jabeen, R. 2005. Foliar spray of mineral elements antagonistic to sodium- A Technique to induce salt tolerance in plant growing under saline conditions. Pak. Jour. Bot., 37(4): 913-920.

[16] Jabeen, R \& Ahmad, R. 2009. Alleviation of the adverse effects of salt stress by foliar application of sodium antagonistic essential minerals of cotton (Gossypium hirsutum L). Pak J Bot 41: 2199-2208.

[17] Diego, A.M., Marta, R.G., Carlos, A.M. \& Macro, A.O. 2004. The effects of salt stress on growth, nitrate reduction and proline and glycinebetaine accumulation in Prosopis alba. Brazi. Jour. Plant Physiol., 16(1):39-46.

[18] Srivastava, H.S. 1990.Regulation of nitrate reductase activity in higher plants.Phytochemistry, 19:725-733. 
[19] Lea, P.J. 1997.Primary nitrogen metabolism. In: Plant Biochemistry.(DAY, P.M. and Harborn, J.B eds.), p. 273-313. Academic Press, New York.

[20] Chaves, MM, Flexas J, \& Pinheiro C. 2009. Photosynthesis under drought and salt stress: regulation mechanisms from whole plant to cell. Ann Bot 103: 551-560.

[21] Dubey, R.S. 1997. Photosynthesis in plants under stressful conditions. In: Handbook of photosynthesis. (Ed.): M. Pessarakli. New York: Marcel Dekker, p. 859-875.

[22] M. Jamil, S. Rehman, E.S. Rha. 2007a.Salinity effect on plant growth, ps11 photochemistry and chlorophyll content in sugar beet (Beta vulgaris L.) and cabbage (Brassica oleracea capitata L.)Pak. J. Bot., 39 (3) (2007), pp. 753-760.

[23] Bayuelo-Jimenez, J. S., Jasso-Plata, N., \& Ochoa, I. 2012. Growth and Physiological responses of Phaseolus species to salinity stress. International Journal of Agronomy.http://dx.doi.org/10.1155/2012/527673.

[24] Cramer, G.R. \& Novak, R.S. 1992. Supplemental manganese improves the relative growth, net assimilation and photosynthetic rates of salt-stressed barley. Physiol. Plant., 84: 600-605.

[25] Marschner, H. 1995.Mineral nutrition of higher plants.pp.229299. Academic press, San Diego Abou El-Nour, E.A.A. 2002. Can Supplemented Potassium Foliar Feeding Reduce the Recommended Soil Potassium? Pak. Jour. Biol. Sci., 5(3): 259-262.

[26] Lidon, F.C. \& Teixeira, M.G. 2000. Rice tolerance to excess $\mathrm{Mn}$ : Implications in the chloroplast lamellae and synthesis of a novel Mn protein. Plant Physiol. and Biochem., 38(12):969978(10).

[27] Tector, A.B., 1991. Determination of Kjeldhal nitrogen content with Kjeltec autosystems I, II, III and IV. Tector application note AN 30/81, Hoganas, Sweden.

[28] Yashoda, S., D.A Forno, J. H. Cock \& K.A. Gomez 1976. Laboratory Manual of physiological studies of Rice IRRI, Los Banos, Philippines.

[29] Kannan S. 2010. Foliar fertilization for sustainable crop production. Sustainable Agriculture Reviews 4: 371- 402

[30] King, B. J., Siddiqui, M.Y. and Glass, A.D.M. 1992. Studies of the uptake of nitrate in barely. V. Estimation of root cytoplasmic nitrate concentration using reductase activity implications for nitrate influx. Plant Physiol., 99: 1582-1589.

[31] Krogmann, D. W. and Jagendorf, A.T. 1958.A Spectrophotometric assay of the Hill Reaction with ferricyanide. Plant Physiol., 32: 373-374.

[32] SPSS. 2005. SPSS: SPSS 11.0 for Windows 98. Chicago: SPSS, Inc.

[33] Duncun, D.B. 1955. Multiple ranges and multiple F-tests. Biometrics. 11: 1-42.

[34] Cazetta, J.S. \& Villela, L.C.V. 2004. Nitrate reductase activity in leaves and stems of tanner grass (Brachiaria radicansNapper). Scient. Agrico., 61(6):652-658.
[35] Guleryuz, G. \& Arsalan, H. 1999. Nitrate Reductase Activity in Verbascum L.(Scrophulariaceae) Species from the Eastern Mediterranean in Dependence on Altitude. Turk. Jour. Bot., 23:89-96.

[36] Abd El-Samad, H.M., El-Komy, H.M., Shaddad, M.A.K. \& Hetta, A.M. 2005.Effect of molybdenum on nitrogenase and nitrate reductase activities of wheat inoculated with Azosporillium brasilense grown under drought stress. Jour. Appl. Plant Physiol., 31(1-2):43-54.

[37] Roberts, N.J. \& Menary, R.C. 1994.Effect of nitrogen on growth, flower yield, oil composition, and yield in [Boroniamegastigma (L.)Nees. Jour. Plant Nutri., 17(12) p. 2035-2052.

[38] Barthes, L., Deleens, E., Bousser, A., Hoarau, J. \& Jean-Louis Prioul. 1996. Xylem exudation is related to nitrate assimilation pathway in detopped maize seedlings: use of nitrate reductase and glutamine synthetase inhibitors as tools. Jour. Exp. Bot., 47(297) pp. 485-495.

[39] Kawachi, T., Sueyoshi, K., Nakajima, A., Yamagata, H., Sugimoto, T. \& Oji, Y. 2002.Expression of asparagine synthetase in rice (Oryza sativa) roots in response to nitrogen. Physiol. Plantrum., 114(1):41-46.

[40] Dordas C., Slavko, P., Brown, P.H., Connell, J.H., Nyomora, A.M. S., Hening, H. and Stangoulis, J. 2001. Foliar boron application improves flower fertility and fruit set of olive. Hort.Sci., 36(4):639-644.

[41] Hasegawa, P.M., R.A. Bressan, J.K. Zhu and H.J. Bohnert. 2000. Plant cellular and molecular responses to high salinity. Annu. Rev. Plant Physiol. Plant Mol. Biol., 51: 463-499.

[42] Munns, R. 2002. Comparative physiology of salt and water stress. Plant, Cell and Environ, 25: 239-250.

[43] Ashraf, M. \&M. Shahbaz. 2003. Assessment of genotypic variation in sal $t$ tolerance of early CIMMYT hexaploid wheat germplasm using photosynthetic capacity and water relations as selection criteria. Photosynthetica, 41:273-280.

[44] Ashraf, M. 2004. Some important physiological selection criteria for salt tolerance in plants. Flora, 199(5): 361-376.

[45] Jabeen, N \& Ahmad, R. 2011. Effect of foliar-applied boron and manganese on growth and biochemical activities in Sunflower under saline conditions. Pak. J. Bot., 43(2): 1271$1282,2011$.

[46] Lidon, F.C. \& M.G. Teixeira. 2000. Rice tolerance to excess Mn: Implications in the chloroplast lamellae and synthesis of a novel Mn protein. Pant. Physiol. and Biochem, 38(12): 969978(10).

[47] Krogmann, D. W. \& Jagendorf, A.T. 1958.A Spectrophotometric assay of the Hill Reaction with ferricyanide. Plant Physiol., 32: 373-374.

[48] Kenneth, E. F. 1970. Some factors affecting the Hill activity in Cotton Chloroplasts ${ }^{1}$. Plant Physio, 45:465-469. 